\title{
Identification of germ-line chimaeras by polymerase chain reaction and isoenzyme analysis of mouse spermatozoa
}

\author{
G. B. Mann, K. J. Fowler*, D. Grail and A. R. Dunn \\ Melbourne Tumour Biology Branch, Ludwig Institute for Cancer Research, PO Royal Melbourne \\ Hospital, Victoria 3050, Australia
}

\begin{abstract}
In this study a rapid, simple and inexpensive procedure is described which allows potential germ-line male mice to be identified with confidence. Spermatozoa recovered by uterine washing following mating with normal female mice was analysed in two ways. First, the patterns of expression of the different isoforms of glucose phosphate isomerase were determined. Since the glucose phosphate isomerase isoforms expressed in embryo stem (ES) cell lines are frequently different from those associated with the host blastocyst, it is possible to determine the proportion of spermatozoa produced by an individual animal that was of ES cell or host-blastocyst origin. Second, DNA of spermatozoa was subjected to polymerase chain reaction (PCR) analysis using primers with specificity for the targeted mutation in the ES cells. The PCR analysis was particularly valuable in identifying germ cell chimaeras in which the contribution of ES-derived spermatozoa was significantly less than that specified by the host blastocyst.
\end{abstract}

\section{Introduction}

Mouse embryonic stem cells (ES cells) derived from the inner cell mass of day 3.5 blastocysts (Evans and Kaufman, 1981; Martin, 1981) can be cultured indefinitely on feeder cells or in growth medium supplemented with leukaemia inhibitory factor (LIF) (Williams et al., 1988). The ability to propagate ES cells in vitro without compromising their developmental potential provides an opportunity for creating targeted mutations by homologous recombination (for review see Capecchi, 1989). Modified ES cells generated in this way can be microinjected into mouse blastocysts, which in turn can be transferred into recipient mice to generate germline chimaeras. Through interbreeding of heterozygous offspring, animals homozygous for the desired mutation can be produced. Mice with dominant or recessive mutations have been successfully generated in a number of laboratories (for reviews see Capecchi, 1989; Joyner, 1991; Koller and Smithies, 1992).

In most experiments involving the introduction of genetically modified ES cells into blastocysts, the long-term goal is the production of animals homozygous for the desired mutation; it is therefore usual to use animals displaying some level of coat chimaerism for subsequent breeding programmes. In some instances, the coat may appear to be wholly derived from the introduced ES cells, while in other cases the contribution may amount to a few patches of isolated hairs on a background specified by the choice of host blastocyst. Obviously, the composition of subsequent litters sired by any male chimaera is dictated solely by the germ cells that may originate from the introduced ES cells, cells of the host blastocyst or both. One of

${ }^{*}$ Correspondence.

Received 31 December 1992. the principal influences on germ-line transmission is the sex of the host blastocyst (Zijlstra et al., 1989), whereas coat colour composition is determined by the random integration of ES cells into the mesoderm of the host blastocyst (Koller et al., 1989). Thus, coat chimaerism serves only to identify animals in part derived from the introduced ES cells and the degree of chimaerism is, at best, a rough guide to their germ-line potential.

When the outcome of a particular experiment involving injection of ES cells into blastocysts is a collection of low level coat chimaeras, it is often difficult to decide which animals to use as founder members of a breeding programme. In the event that only a small proportion of germ cells are derived from the introduced ES cells, it is quite possible that all the offspring in a particular litter would be of host blastocyst origin. In some instances male chimaeras transmitted the ES cell genotype to fewer than 3\% of their offspring (Zijlstra et al., 1989; DeChiara et al., 1990; Grusby et al., 1991). The number of chimaeras chosen to serve as foundation members of a breeding programme is dictated by factors such as the availability of resources. These considerations would undoubtedly profit from some knowledge of the potential that any particular animal has for germ-line transmission.

In the present study we outline a scheme for assessing the likelihood that any particular chimaeric animal will transmit the genetic modification through the germ line. The procedure involves glucose phosphate isomerase isoenzyme and PCR analysis of spermatozoa derived from individual chimaeric animals. By judicious choice of oligonucleotide primers, PCR analysis provides a sensitive measure of whether the germ cells of a particular male chimaera are in part derived from the genetically modified ES cells. Isoenzymic analysis takes advantage of electrophoretic differences between isomers encoded by 
the glucose phosphate isomerase Is gene, in tissues originating from the host blastocyst and introduced ES cells (Bradley et al., 1987). The ratio of these isoforms provides a rational basis for establishing breeding programmes using particular chimaeric animals which have the greatest potential for transmitting the genetic trait through the germ line.

\section{Materials and Methods}

\section{Cell cultures}

E14 ES cells (Handyside et al., 1989) were grown on feeder layers of irradiated or mitomycin C-treated STO $\mathrm{Neo}^{\mathrm{r}}$ mouse fibroblasts in Dulbecco's modified Eagle medium with sodium pyruvate and high glucose (Irvine Scientific, Santa Ana, CA) containing 15\% heat-inactivated fetal bovine serum (Cytosystems, Castle Hill), non-essential amino acids (Flow Laboratories, Seven Hills), nucleosides, $10^{-4} \mathrm{~mol} \beta$-mercaptoethanol $1^{-1}$ (Sigma, St Louis, MO), $10^{3} \mathrm{U}$ murine LIF $\mathrm{ml}^{-1}$ (Esgro; Amrad, Melbourne) plus $60 \mu \mathrm{g}$ benzyl penicillin $\mathrm{ml}^{-1}$ (sodium salt, CSL, Parkville) and $100 \mu \mathrm{g}$ streptomycin sulfate $\mathrm{ml}^{-1}$ (CSL, Parkville). All culture surfaces were treated with gelatin (Robertson, 1987). Incubation was at $37^{\circ} \mathrm{C}$ in a humidified atmosphere of $10 \% \mathrm{CO}_{2}$. Cells were tested mycoplasma free using the Gen-probe Rapid Detection System and by Hoechst 33258 staining (Chen, 1977).

\section{Generation of chimaeric mice}

Approximately 15 ES cells were injected into blastocysts and late morulae flushed from superovulated and naturally mated C57BL/ 6 mice (4-5 weeks old). After injection, embryos were cultured for $4-20 \mathrm{~h}$ in HTF medium (Quinn et al., 1982) or in M16 medium (Hogan et al., 1986). Twelve to twenty embryos with visible blastocoels were transferred to the uteri of pseudopregnant random-bred Swiss and $\mathrm{F}_{1}(\mathrm{C} 57 \mathrm{BL} / 6 \times \mathrm{CBA} / \mathrm{CaH})$ recipients (8-12 weeks old) at 2.5 days post coitum, as described by Bradley (1987). Pups were born 17-18 days after transfer. Heavily chimaeric pups were identified 2-3 days later.

Experiments were conducted in accordance with the Royal Melbourne Hospital Campus Animal Ethics Committee (Parkville, Australia). Mice were purchased from Animal Resources Centre (Willetton). Mice were housed in standard shoebox mouse cages and were fed with feeder cubes (Barastoc ARM diet, Pakenham) and were given water ad libitum.

\section{Collection of spermatozoa}

Fertile male mice were kept on a $16 \mathrm{~h}$ light $(16: 00-08: 00 \mathrm{~h})$ : $8 \mathrm{~h}$ dark cycle. At 08:00 h, female mice (6-10 weeks old) were given an i.p. injection of 2.5 i.u. human chorionic gonadotrophin ( $\mathrm{hCG}$; Chorulon; Intervet, Lang Cove) and were immediately housed with male mice. Female mice were examined for vaginal plugs every $2 \mathrm{~h}$. Once a plug was observed, female mice were killed by cervical dislocation and their reproductive tracts removed. Spermatozoa were flushed from each uterine horn using a $2 \mathrm{ml}$ disposable syringe attached to a 27-gauge needle.

Spermatozoa samples for glucose phosphate isomerase analysis were collected in $0.2-0.5 \mathrm{ml}$ distilled water, whereas samples for PCR were collected in 1-2 ml PBS. Samples were
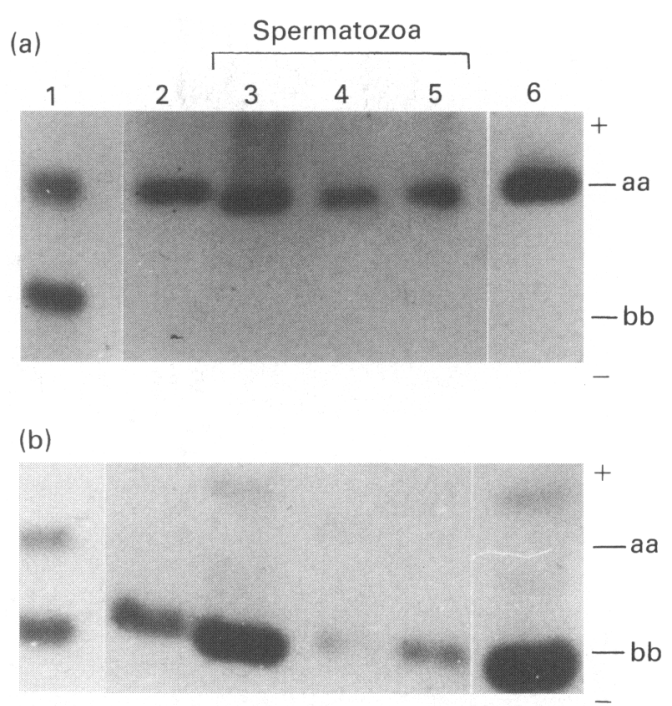

Fig. 1. Glucose phosphate isomerase-1s (Gpi-1s) analysis of tissues from (a) male 129/SvHe and (b) C57BL/6 mice. Markers (lane 1) are a mixture of blood from 129/SvHe and C57BL/6 mice. Blood (lane 2), spermatozoa from the epididymis (lane 3 ) and spermatozoa from uterine flushing of both 129/SvHe (lane 4) and C57BL/6 (lane 5) females as well as testis (lane 6) are shown. The direction of the electrophoretic field $(+/-)$ and the position of the Gpi-Is ${ }^{\mathrm{aa}}$ (marked aa) and Gpi-Is ${ }^{\mathrm{bb}}$ (marked bb) isoforms are indicated.

examined by microscope for the presence of motile spermatozoa. Particular care was taken with the collection of samples for glucose phosphate isomerase analysis to avoid contamination with maternal blood.

\section{Glucose phosphate isomerase analysis}

All samples for glucose phosphate isomerase analysis were lysed in distilled water and kept frozen. Glucose phosphate isomerase analysis was carried out using Titian III Zip Zone cellulose acetate plates (Helena Laboratories, Beaumont, $T X$ ) as described by Bradley (1987).

Estimation of the percentage of ES cell contribution in blood and spermatozoa was done on glucose phosphate isomerase plates using Chromoscan 3 (Joyce Loebl, Vickers Instruments Inc., Malden MA) at $530 \mathrm{~nm}$ and with $0.3 \mathrm{~mm}$ aperture width.

\section{$P C R$ analysis}

PCR conditions were established on cells that had been transfected with a vector containing both primer binding sites. Cells were washed with phosphate-buffered saline (PBS) and then lysed in a solution of $0.5 \% \mathrm{SDS}, 0.1 \mathrm{~mol} \mathrm{NaCl} \mathrm{l} \mathrm{N}^{-1}, 0.01 \mathrm{~mol}$ EDTA $\mathrm{l}^{-1}, 0.1 \mathrm{~mol}$ Tris- $\mathrm{HCl} \mathrm{l}^{-1} \mathrm{pH} 7.5$ and $0.5 \mathrm{mg}$ pronase $\mathrm{ml}^{-1}$. Sperm samples that had been collected in PBS were spun at 5000 r.p.m. for 3 min using Biofuge $\mathrm{A}$ (Heraeus Christ; Foss Electric Australia Pty. Ltd, Melbourne); the supernatant was removed and the cell pellet resuspended in lysis buffer. All samples were incubated at $55^{\circ} \mathrm{C}$ for $2 \mathrm{~h}$. After a phenol and a chloroform extraction, the DNA was precipitated in isopropanol, and resuspended in Tris-EDTA buffer at about $250 \mathrm{ng} \mathrm{Il}^{-1}$. PCR was carried out in a final volume of $20 \mu \mathrm{l}$ containing $0.067 \mathrm{~mol}$ Tris- $\mathrm{HCl} \mathrm{l}{ }^{-1}, 0.00166 \mathrm{~mol}\left(\mathrm{NH}_{4}\right)_{2} \mathrm{SO}_{4} \mathrm{l}^{-1}, 0.45 \%$ 

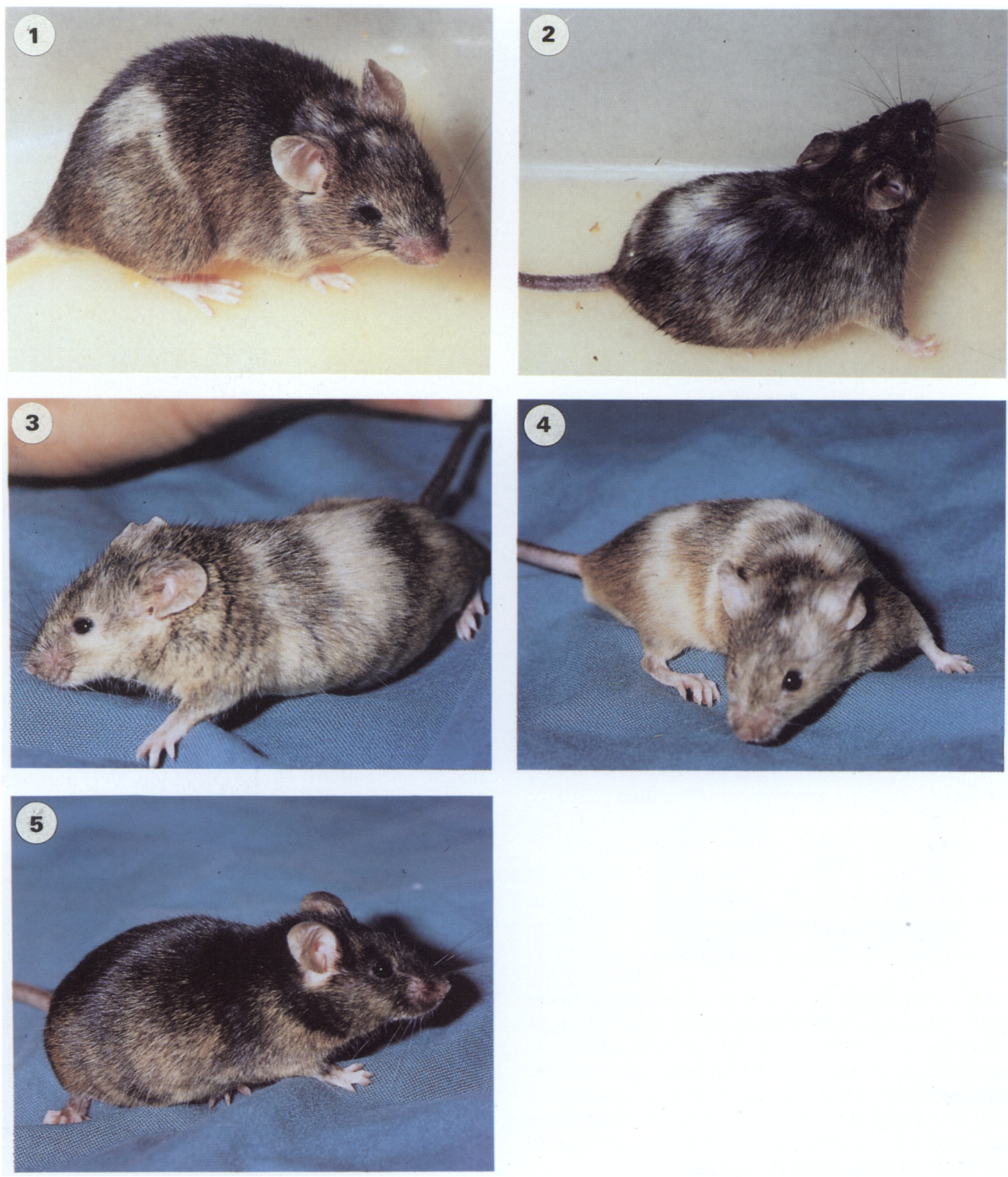

Fig. 2. The five E14-C57BL/6 chimaeras used for Gpi analysis and test breeding.

Triton X-100, $20 \mu \mathrm{g}$ gelatin $\mathrm{ml}^{-1}, 0.002 \mathrm{~mol} \mathrm{MgCl}_{2} \mathrm{l}^{-1}$, $250 \mu \mathrm{mol} \mathrm{l}^{-1}$ of each dNTP; $10 \mathrm{ng}$ of each primer and $1 \mathrm{U}$ of Taq polymerase. Thirty-five temperature cycles were used as follows: $95^{\circ} \mathrm{C}, 50 \mathrm{~s} ; 63^{\circ} \mathrm{C}, 50 \mathrm{~s} ; 72^{\circ} \mathrm{C}, 70 \mathrm{~s}$, after an initial denaturation step at $95^{\circ} \mathrm{C}$ for $150 \mathrm{~s}$.

The following synthetic oligonucleotide primers were used to identify the rearranged transforming growth factor $\alpha$ (TGF- $\alpha$ ) locus. $5^{\prime}$-sense primer is taken from the sequence of a genomic fragment adjacent to the targeting vector and is: $5^{\prime}$ dGACTAGCCTGGGCTACACAGTG-3' (Mann et al., 1993). 3 -antisense primer is derived from the neomycin gene (Tn5, nucleotides 2264-2285, Colbere-Garapin et al., 1981) and is 5'-dCCGCTTCCTCGTGCTTTACGGT-3'.
Five microlitres of the reaction mix was resolved on a $1 \%$ agarose gel and stained with ethidium bromide, prior to photography.

\section{Results}

Isoenzymic analysis of spermatozoa

We exploited the fact that glucose phosphate isomerase- $1 \mathrm{~s}$ is expressed in spermatozoa (Brock, 1977) as the basis for assessing whether the spermatozoa of individual chimaeric animals was derived from cells of the host blastocyst or from ES cells 

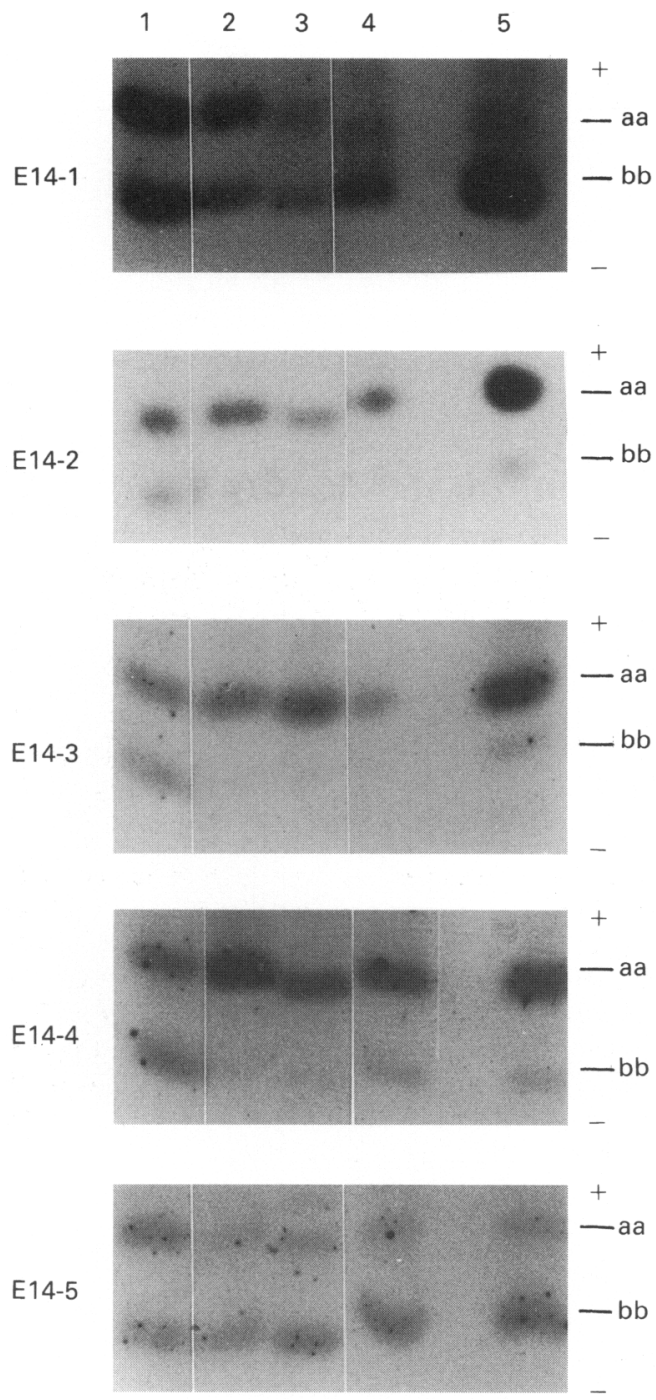

Fig. 3. Glucose phosphate isomerase-1s (Gpi-1s) analysis of tissues from E14-C57BL/6 chimaeras 1-5. Markers (lane 1) are a mixture of blood from 129SvHe and C57BL/6 mice. Extracts of blood (lane 2), epididymis-derived spermatozoa (lane 3) and testis (lane 5) were harvested after mice were killed. Spermatozoa were collected by uterine flushing of a $\mathrm{C} 57 \mathrm{BL} / 6$ female (lane 4). The direction of the electrophoretic field $(+/-)$ and the position of the Gpi-1s ${ }^{\mathrm{aa}}$ (marked aa) and Gpi-1s ${ }^{b b}$ (marked bb) isoforms are indicated.

introduced into blastocysts by microinjection. We reasoned that since the ES cells used for gene targeting are usually derived from a different mouse strain to that of the host blastocyst, it might be possible to assess the origin of the spermatozoa by taking advantage of the fact that different strains of mice express different isomers of glucose phosphate isomerase (Green, 1989).

We first set out to establish the patterns of glucose phosphate isomerase expression in spermatozoa from 129/SvHe (Pease et al., 1990) and C57BL/6 mice. The choice of these strains simulates the combination of ES cells (E14, Handyside et al., 1989) and the host blastocyst $(\mathrm{C} 57 \mathrm{BL} / 6)$ that are routinely used for gene targeting exercises in our laboratory. Sperm samples from $129 / \mathrm{SvHe}$ and $\mathrm{C} 57 \mathrm{BL} / 6$ male mice were recovered by uterine
Table 1. Germ-line transmission of E14-derived male mouse chimaeras

\begin{tabular}{lcc}
\hline Chimaera & $\begin{array}{c}\text { Estimated percentage of } \\
\text { ES cell contribution } \\
\text { by coat colour }\end{array}$ & $\begin{array}{c}\text { Number of } \\
\text { agouti versus } \\
\text { total offspring }\end{array}$ \\
\hline 1 & $5 \% \mathrm{c}^{\mathrm{ch}}, 95 \% \mathrm{~A}$ & ${ }^{*} 0 / 23$ \\
2 & $10 \% \mathrm{c}^{\mathrm{ch}}, 90 \% \mathrm{~A}$ & ${ }^{*} 17 / 17$ \\
3 & $25 \% \mathrm{c}^{\mathrm{ch}}, 75 \% \mathrm{~A}$ & $17 / 17$ \\
4 & $25 \% \mathrm{c}^{\mathrm{ch}}, 75 \% \mathrm{~A}$ & $13 / 13$ \\
5 & $25 \% \mathrm{~A}, 75 \% \mathrm{~B}$ & ${ }^{*} 4 / 20$ \\
\hline
\end{tabular}

Coat colours, $\mathrm{c}^{\text {ch }}$ : chinchilla; A: agouti; B: black. Black hair indicates absence of contribution of ES cells. Agouti indicates that $F_{1}$ mice are heterozygous for E14 genetic material (Koller et al., 1989).

"E14-1 embryos, one dead E14-2 pup and one dead E14-5 pup were analysed by glucose phosphate isomerase.

washing following mating with hCG-treated 129/SvHe and C57BL/6 females. Spermatozoa derived from 129/SvHe (Fig. 1a) and C57BL/6 (Fig. 1b) mice express the Gpi-1s ${ }^{\text {aa }}$ and $\mathrm{Gpi}^{-1 s^{\mathrm{bb}}}$ isoforms, respectively, which are clearly distinguished by their different electrophoretic mobilities. For both $129 / \mathrm{SvHe}$ and C57BL/6 males, only the respective Gpi-Is ${ }^{a a}$ and Gpi-Is ${ }^{b b}$ isoforms are present indicating that the method of spermatozoa collection had not resulted in significant contamination by tissues of the female mice to which individual males had been mated. The patterns of expression of isoforms of glucose phosphate isomerase (Fig. I) detected in spermatozoa recovered from the epididymides, testes and blood of 129/SvHe (Fig. 1a) and $\mathrm{C} 57 \mathrm{BL} / 6$ (Fig. Ib) male mice was the same as that detected in spermatozoa recovered from uterine washing.

\section{Analysis of glucose phosphate isomerase of chimaeric mice}

A series of chimaeric animals were generated following injection of E14 ES cells into C57BL/6 blastocysts, to establish whether typing glucose phosphate isomerase isomers in spermatozoa might provide a basis for predicting the genetic composition of offspring. E14 cells, derived from strain 129/Ola $\left(\mathrm{A}^{\mathrm{w}} \mathrm{c}^{\mathrm{ch}} \mathrm{p}\right)$ mice, carry mutations at three loci, agouti $(A)$, albino (c) and pink-eyed ( $p$ ) that are known to affect coat colour. The 129/Ola mice have pale cream coat colour and pink eyes (Koller et al., 1989). C57BL/6-E14 chimaeras are readily identified 7 days after birth by lighter patches of fur on a black background. Of the numerous animals we have generated in this way, five male chimaeras were selected for detailed analysis on the basis of the extent and range of coat chimaerism displayed by each animal (Fig. 2). These animals were typical of those routinely generated in our laboratory using this combination of ES cell and host blastocyst. Each chimaera was mated with a $\mathrm{C} 57 \mathrm{BL} / 6$ female; spermatozoa were recovered by uterine washing and the pattern of glucose phosphate isomerase isoforms was determined (Fig. 3). In the case of chimaera E14-1, the main isoform was Gpi-Is ${ }^{\text {bb }}$, indicating that the ejaculated spermatozoa were predominantly of $\mathrm{C} 57 \mathrm{BL} / 6$ origin. By contrast, spermatozoa recovered from E14-2 and E14-3 displayed the Gpi-1s ${ }^{\text {aa }}$ isoform, suggesting that the spermatozoa of these animals was of Downloaded from Bioscientifica.com at 04/26/2023 02:26:29AM 
(a)

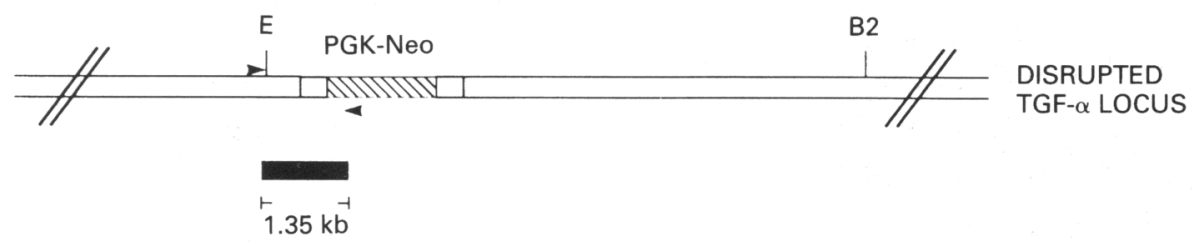

(b)

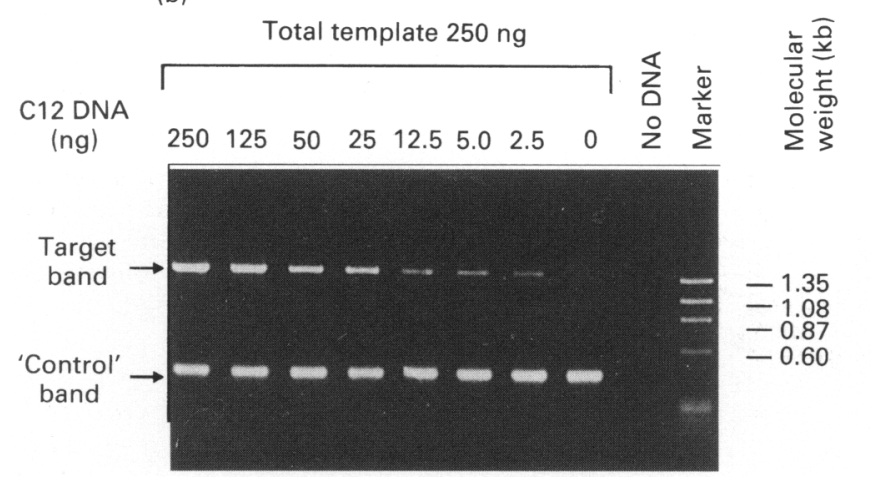

(c)

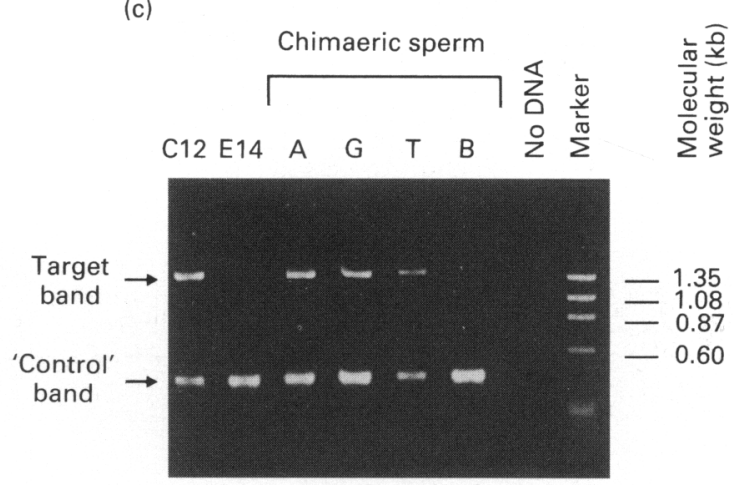

Fig. 4. (a) Schematic representation of disrupted transforming growth factor $\alpha$ (TGF- $\alpha$ ) allele. Predicted structure of disrupted TGF- $\alpha$ locus. Arrowheads indicate the position of the diagnostic oligonucleotide primers. The $5^{\prime}$-sense primer sequence lies $5^{\prime}$ to the EcoR 1 site that marked the limit of homology in the targeting vector. The $3^{\prime}$-antisense primer sequence lies at the $3^{\prime}$ end of the neo coding sequence. Filled box represents the diagnostic $1.35 \mathrm{~kb}$ PCR band. PGKNeo:neomycin phosphotransferase coding sequence, under control of murine phosphoglycerol kinase regulatory elements; E:EcoR1; B2:BgIII. (b) PCR analysis of DNA from ES cell lines. DNA from targeted cells, C12, and from parental ES cells, E14, mixed in various ratios then subjected to PCR analysis using diagnostic primers. An unexplained 'control' band is seen in all PCR using these primers and murine DNA. A diagnostic band is present when the targeted DNA is present in a 1:100 dilution. (c) PCR analysis of DNA from chimaeric mouse spermatozoa. PCR on DNA from control ES cell lines and from spermatozoa samples of four chimaeras, A, T, G and B, with and without germ-line potential.

Table 2. Characteristics of transforming growth factor $\alpha$ (TGF- $\alpha$ ) mouse chimaeras

\begin{tabular}{lcccc}
\hline & \multicolumn{2}{c}{ Estimated percentage of ES cell contribution } & \\
\cline { 2 - 3 } Chimaera & $\begin{array}{c}\text { Coat } \\
\text { colour }\end{array}$ & $\begin{array}{c}\text { Blood } \\
(\%)\end{array}$ & $\begin{array}{c}\text { Spermatozoa } \\
(\%)\end{array}$ & $\begin{array}{c}\text { Number of } \\
\text { agouti versus } \\
\text { total offspring }\end{array}$ \\
\hline A & $25 \% c^{\text {ch }}, 75 \% \mathrm{~A}$ & 51 & 99 & $* 44 / 44$ \\
$\mathrm{~T}$ & $15 \% \mathrm{c}^{\mathrm{c}}, 85 \% \mathrm{~A}$ & 38 & 35 & $19 / 58$ \\
$\mathrm{G}$ & $25 \% \mathrm{~A}, 75 \% \mathrm{~B}$ & 30 & 25 & $* 15 / 57$ \\
$\mathrm{~B}$ & $10 \% \mathrm{c}^{\mathrm{ch}}, 90 \% \mathrm{~W}$ & $\mathrm{NP}$ & $\mathrm{NP}$ & $0 / 32$ \\
\hline
\end{tabular}

Coat colours, $c^{\text {ch: }}$ chinchilla; A: agouti; B: black; W: white; NP: not possible, as mouse B was the result of injection of E14 ES cells into BALB/c blastocysts, both of which express the Gpi-Is aa isoform (see Table 4).

${ }^{*}$ One dead A pup and two dead G pups were analysed by glucose phosphate isomerase.

129/Ola origin. In the case of E14-4 the glucose phosphate isomerase isoform present in spermatozoa was predominantly Gpi-1s ${ }^{\text {aa }}$, although some Gpi-1s ${ }^{\text {bb }}$ was present. Finally, spermatozoa from E14-5 expressed both $\mathrm{Gpi}-1 \mathrm{~s}^{\mathrm{aa}}$ and $\mathrm{Gpi}-\mathrm{Is}{ }^{\mathrm{bb}}$ isoforms at a ratio of about $1: 4$.

Once spermatozoa from chimaeras had been analysed and a breeding programme from each animal had been completed, mice were killed. Spermatozoa were recovered from the epi- didymides and simultaneously samples of blood and testis were collected for glucose phosphate isomerase analysis. For most of the chimaeric animals, (for example E14-2, E14-3, E14-4 and E145 ), the patterns of expression of glucose phosphate isomerase isoforms in blood and epididymides roughly recapitulated that observed in spermatozoa isolated from the same animal following mating. In chimaera EI4-I, the contribution of Gpi-Is ${ }^{\text {aa }}$ was somewhat higher in blood than in spermatozoa or testis. 
Table 3. Predicted number of offspring to secure germline transmission in mice

\begin{tabular}{lrr}
\hline & \multicolumn{2}{c}{$\begin{array}{c}\text { Number of offspring } \\
\text { needed to be analysed }\end{array}$} \\
\cline { 2 - 3 } $\begin{array}{l}\text { Chimaerism of } \\
\text { spermatozoa }\end{array}$ & $P=0.95$ & $P=0.99$ \\
\hline & 299 & 459 \\
1 & 149 & 228 \\
2 & 59 & 90 \\
5 & 29 & 44 \\
10 & 19 & 29 \\
15 & 14 & 21 \\
20 & 9 & 13 \\
30 & 5 & 7 \\
50 & & \\
\hline
\end{tabular}

For various degrees of chimaerism (c), the number of offspring that must be generated $(n)$ to produce at least one ES cell-derived mouse at a confidence level $(p)$ of $95 \%$ or $99 \%$ was calculated using the following equation:

$$
I-\left(\frac{100-c}{100}\right)^{n}<p
$$

\section{Mating data from chimaeric animals}

When the Gpi-isoform profiles were established (Fig. 3) and the degree of coat chimaerism (Fig. 2) of the E14-1-5 mice estimated, the frequency of agouti pups sired by individual chimaeras was determined after mating for approximately 3 months. All of the pups sired by E14-2, -3 and -4 were agouti indicating that the spermatozoa of these animals were mainly, or wholly, derived from the E14 ES cells (Table I). By contrast, none of the pups generated from matings using E14-1, and 20\% of the offspring sired by E14-5 was agouti.

\section{PCR analysis of spermatozoa derived DNA}

Although glucose phosphate isomerase analysis of spermatozoa of male chimaeras in principle provides the basis for predicting the composition of subsequent litters, its general utility is restricted by its sensitivity. When the outcome of a particular series of blastocyst transfers is the generation of a collection of poor chimaeras, it is possible that the proportion of ES cellderived spermatozoa would be so low that it would be undetectable by glucose phosphate isomerase analysis. In these circumstances, it is important to be able to distinguish animals with some potential to transmit the ES cell-associated trait from those whose spermatozoa are wholly of host blastocyst origin. To this end, we used the polymerase chain reaction (Mullis et al., 1986; Saiki et al., 1988) for analysis of sperm DNA (Ficsor et al., 1990) using a pair of oligonucleotide primers with specificity for the modification engineered in the original targeted ES cell line.

The feasibility of using a PCR based screening procedure was assessed by analysing spermatozoa DNA from four male chimaeric animals (designated A, B, G and T) derived from blastocysts injected with E14 ES cells carrying a disruption of the TGF- $\alpha$ locus (Mann et al., 1993). In the context of the present report, the significance of studying these mice is the opportunity afforded by a modified TGF- $\alpha$ locus of using unique oligonucleotide primer binding sites in conjunction with PCR to monitor the origin of the spermatozoa of those animals. The primers used to screen sperm DNA were the same as those originally used to identify ES cells in which a TGF- $\alpha$ targeting vector had recombined with the TGF- $\alpha$ locus by homologous recombination (Fig. 4a). One of the primers ( $3^{\prime}$-antisense) corresponds to sequences of the neomycin gene, and the other lies in the TGF- $\alpha$ locus but outside of the targeting vector ( $5^{\prime}$ sense). Use of DNA from the targeted ES cell line (C12) in a $P C R$ reaction resulted in the generation of a $1.35 \mathrm{~kb}$ product from these primers, which is diagnostic for the disrupted TGF- $\alpha$ locus (Fig. 4b); no corresponding band was generated using DNA from normal E14 cells. To determine the sensitivity of the PCR assay, we set up a reconstruction by mixing DNA from the original targeted ES cell line and normal ES cell DNA. The presence of the disrupted TGF- $\alpha$ locus can be detected when the ratio of targeted ES:normal ES cell DNA is 1:100 (Fig. 4b).

DNA was subjected to PCR analysis using the diagnostic primers to determine whether spermatozoa from animals $A, G$. $T$ and $B$ included the TGF- $\alpha$ disruption. Sperm DNA from mice $\mathrm{A}, \mathrm{G}$ and $\mathrm{T}$ but not mouse $\mathrm{B}$ contained the diagnostic $1.35 \mathrm{~kb}$ fragment (Fig. 4c). Spermatozoa samples positive by PCR were also subjected to glucose phosphate isomerase analysis and the relative proportion of Gpi-1s $\mathrm{s}^{\mathrm{aa}}$ and $\mathrm{Gpi}-1 \mathrm{~s}^{\mathrm{bb}}$ isoforms in blood and spermatozoa from these animals was determined densitometrically (Table 2). The three animals (A, $T$ and $G$ ) showing evidence of a disrupted TGF- $\alpha$ locus were subsequently introduced into a breeding programme to determine the relationship between the relative proportion of glucose phosphate isomerase isoforms and transmission of the ES cell genotype. All of the offspring of mouse A were agouti, indicating transmission of ES cell-derived genetic material (Table 2). As predicted from glucose phosphate isomerase analysis of spermatozoa, about $35 \%$ of the offspring of mouse T and $25 \%$ of the offspring of mouse $G$ were agouti.

\section{Discussion}

Transgenic mouse projects based on embryonic stem cells tend to be characterized by many blastocyst injections which, in turn, lead to the generation of many litters. Mice, which are wholly, or in part, derived from genetically modified ES cells are identified on the basis of coat chimaerism. While the extent of coat chimaerism is often used as an indirect guide to germ-line potential, it does not indicate whether the primitive gonads of a particular animal have been colonized by ES cells, leading to germ-line transmission. This is exemplified in the case of two animals generated in the present study following injection of normal EI4 ES cells into C57BL/6 blastocysts. On the basis of coat chimaerism we might have expected that E14-1, with no obvious black hair, would have significant ES cell contribution to the germ tissues and likewise, that E14-5, with mainly black hair, was unlikely to have germ-line potential. In neither case was the extent of coat chimaerism a valuable guide to germ-line potential, based on the offspring sired by each of these animals. 
Table 4. Glucose phosphate isomerase (Gpi-Is) isoforms of ES cell lines and mouse blastocysts

\begin{tabular}{|c|c|c|c|}
\hline \multicolumn{2}{|r|}{ Parental ES cell } & \multicolumn{2}{|r|}{ Host blastocyst } \\
\hline Cell line & Gpi-Is isoform & Mouse strain & Gpi-Is isoform \\
\hline $\begin{array}{l}\text { ES-D3 } \\
\text { E14 } \\
\text { MBL5 } \\
\text { CCE } \\
\text { CC1 } \\
\text { CP1 }\end{array}$ & $\begin{array}{l}\text { aa (Gossler et al., 1986) } \\
\text { aa (Hooper et al., 1987) } \\
\text { aa* } \\
\text { cc (Schwartzberg et al., 1989) } \\
\text { cc (Bradley et al., 1984) } \\
\text { aa (Bradley et al., 1984) }\end{array}$ & $\begin{array}{l}\text { C57BL/6 } \\
\text { ICR } \\
\text { PO } \\
\text { MFI } \\
\text { CDI } \\
\text { CFLP } \\
\text { BALB/c }\end{array}$ & $\begin{array}{l}\text { bb (Green, 1989) } \\
\text { bb (Boulter et al., 1991) } \\
\text { bb (Boulter } \text { et al., 1991) } \\
\text { bb (Beddington and Robertson, 1989) } \\
\text { bb (Schwartzberg et al., 1989) } \\
\text { bb (Bradley et al., 1984) } \\
\text { aa (Green, 1989) }\end{array}$ \\
\hline
\end{tabular}

*Authors' unpublished observation.

Clearly, some knowledge of the potential for germ-line transmission would be of considerable value to enable rational allocation of resources.

In the present study, glucose phosphate isomerase analysis was used to determine whether spermatozoa produced by animals displaying coat chimaerism is of $129 / \mathrm{Ola}$ or C57BL/6 origin or both. As predicted, the litters sired by E14-2 and E143 were all agouti, reflecting the fact that only the Gpi-Is ${ }^{\text {aa }}$ isoform was detected in spermatozoa derived from these animals. Because these chimaeras had $100 \%$ transmission, they were probably derived from injected female host blastocysts (Zijlstra et al., 1989). In the case of E14-4, all of the offspring were agouti, reflecting the predominance of the Gpi-1s ${ }^{\text {aa }}$ isoform, although a relatively small proportion of $\mathrm{Gpi}-\mathrm{Is}^{\mathrm{bb}}$ isoform was clearly detected in spermatozoa from this animal. Assuming that ES cell and host blastocyst-derived spermatozoa were equally capable of fertilization, it is likely that some C57BL/6 derived animals would have been generated had E14-4 been used as the founder of a larger collection of offspring.

In the case of E14-1, glucose phosphate isomerase analysis indicated that most of the ejaculated spermatozoa were of C57BL/6 origin, whereas spermatozoa from E14-5 were a mixture of C57BL/6 and 129/Ola. The composition of litters sired by these two mice clearly reflects the patterns of glucose phosphate isomerase isoform distribution in spermatozoa and is at odds with predictions based solely on the extent of coat chimaerism or glucose phosphate isomerase isoform distribution in blood.

On the basis of its simplicity and reliability, we now routinely carry out glucose phosphate isomerase isoform analysis on spermatozoa from any male animal arising from gene targeting exercises before establishing a breeding programme. In addition to indicating whether any particular animal has germ-line potential, the procedure is also semi-quantitative. Thus, on the basis of the ratio of different glucose phosphate isomerase isoforms, it is possible to predict mathematically the number of offspring that would need to be sired by an individual germ-line mosaic mouse to be confident of securing at least one ES-cell derived pup. For example, germ-line transmission would be expected in the first litter where the father was a $50 \%$ germ-cell mosaic. Where the contribution of ES cell-derived spermatozoa was only 5 or $10 \%$ it would be necessary to generate 59 and 29 offspring, respectively, to be certain of securing germ-line transmission at a confidence level of $95 \%$. A basic assumption underlying this approach is that spermatozoa from chimaeric testes are produced from both groups of germ cells at a fixed ratio and that all spermatozoa are equally likely to fertilize an ovum. A longitudinal study comparing germ-line contribution in sperm samples with breeding data would be of interest; however, this was not possible because the majority of chimaeras were killed after breeding for approximately 3 months.

However, the usefulness of glucose phosphate isomerase isoform analysis of spermatozoa is limited by its sensitivity. On the basis of reconstruction experiments, we are confident that we can observe the Gpi-1sb isoform where the proportion of $\mathrm{Gpi}-1 \mathrm{~s}^{\mathrm{bb}}$ isoform is greater than $5 \%$ (data not shown). However, there have been reports of males that transmit the predetermined mutation at a very low frequency; from less than $1 \%$ to 3\% (Zijlstra et al., 1989; DeChiara et al., 1990; Grusby et al., 1991). Presumably, these low level germ-line chimaeras would have been missed by glucose phosphate isomerase analysis of spermatozoa, as detection of the ES cell associated glucose phosphate isomerase isoform would fall below the sensitivity of the assay.

So that low level germ-cell chimaeras are not discarded solely on the basis of glucose phosphate isomerase analysis, we routinely subject an additional spermatozoa aliquot to PCR analysis. This is conveniently carried out using a pair of oligonucleotides with specificity for the mutation installed in the ES cells. Although the sensitivity of this analysis depends, to some extent, on the nature of any particular pair of oligonucleotides, in practice there should be little difficulty in identifying one part 129-derived spermatozoa in a background of one hundred parts C57BL/6 spermatozoa. Where the level of germ cell chimaerism falls below 1:100, the number of matings required to stand any chance of securing germ-line transmission would be prohibitive.

In summary, we believe that a combination of glucose phosphate isomerase and PCR analysis of spermatozoa from chimaeric animals has the potential to identify animals on which to base breeding programmes. While the animals that form the basis of the present study where derived following injection of E14 cells into C57BL/6 blastocysts, the technique can also be applied to other ES cell-blastocyst combinations which express the $\mathrm{Gpi}-1 \mathrm{~s}^{\mathrm{aa}}$ (or $\mathrm{Gpi}-1 \mathrm{~s}^{\mathrm{cc}}$ ) and $\mathrm{Gpi}-1 \mathrm{~s}^{\mathrm{bb}}$ isoforms, respectively. 
Of the combinations we have surveyed, only $\mathrm{BALB} / \mathrm{c}$ blastocysts express the Gpi-1s ${ }^{\text {aa }}$ isoform and thus glucose phosphate isomerase analysis of spermatozoa cannot be used when BALP/c blastocysts are used in conjunction with ES cells expressing the Gpi-Is ${ }^{\text {aa }}$ isoform.

The authors thank M. Hooper for the gift of E14 cells, L. Robertson for STO Neo cells and G. Rennie for help with statistics. T. Helman, W. Hebb and J. Merryfull are thanked for care of mice and assistance with collection of sperm samples. We are grateful to G. Wood for synthesizing the oligonucleotides and E. Stanley, T. Burgess and G. Hodgson for their comments on the manuscript.

\section{References}

Beddington RSP and Robertson EJ (1989) An assessment of the developmental potential of embryonic stem cells in the midgestation mouse embryo Development 105 733-737

Boulter CA, Aguzzi A, Williams RL, Wagner EF, Evans MJ and Beddington R (1991) Expression of $v$-src induces aberrant development and twinning in chimaeric mice Development 111 357-366

Bradley A (1987) Production and analysis of chimaeras. In Teratocarcinomas and Embryonic Stem Cells a Practical Approach, pp 113-151 Ed EJ Robertson. IRL Press, Oxford, Washington DC

Bradley A, Evans M, Kaufman MH and Robertson EJ (1984) Formation of germline chimaeras from embryo-derived teratocarcinoma cell lines Nature $\mathbf{3 0 9}$ 255-256

Brock WA (1977) Evidence against gene expression after meiosis in the male mouse Journal of Experimental Zoology 202 69-80

Capecchi MR (1989) The new mouse genetics: altering the genome by gene targeting Trends in Genetics 3 70-76

Chen TR (1977) In situ detection of mycoplasma contamination in cell cultures by fluorescent Hoechst 33258 stain Experimental Cell Research 104 255-262

Colbere-Garapin F, Horodniceanu F, Kourilsky P and Gerapin A-C (1981) A new dominant selectable marker for higher eukaryotic cells journal of Molecular Biology 150 1-14

DeChiara TM, Efstratiadis A and Robertson EJ (1990) A growth-deficiency phenotype in heterozygous mice carrying an insulin-like growth factor II gene disrupted by targeting Nature 345 78-80

Evans MJ and Kaufman MH (1981) Establishment in culture of pluripotential cells from mouse embryos Nature 292 154-156

Ficsor G, Ginsberg LC, Klepetka JF, McManus TP, Janca FC, Safron AD and Rank KB (1990) Detection of gene mutations in mouse spermatozoa with polymerase chain reaction (PCR) Progress in Clinical Biology Research $\mathbf{3 4 0}$ 213-222

Gossler A, Doetschman T, Korn R, Serfling E and Kemler R (1986) Transgenesis by means of blastocyst-derived embryonic stem cell lines Proceedings of the National Academy of Sciences USA 83 9065-9069

Green MC (1989) Catalog of mutant genes and polymorphic loci. In Genetic Variants and Strains of the Laboratory Mouse, pp 8-278 Eds MF Lyon and AG Searle. Oxford University Press, Oxford
Grusby MJ, Johnson RS, Papaionnou VE and Glimcher LH (1991) Depletion of $\mathrm{CD}^{+} \mathrm{T}$ cells in major histocompatibility complex class II - deficient mice Science 253 1417-1420

Handyside AH, O'Neil GT, Jones M and Hooper ML (1989) Use of BRLconditioned medium in combination with feeder layers to isolate a diploid embryonal stem cell line Roux's Archives of Developmental Biology 198 8-55

Hogan B, Constantini F and Lacy E (1986) Manipulating the Mouse Embryo, A Laboratory Manual. Cold Spring Harbor Laboratory, New York

Hooper M, Hardy K, Handyside A, Hunter S and Monk M (1987) HPRT. deficient (Lesch-Nyhan) mouse embryos derived from germline colonization by cultured cells Nature 326 292-295

Joyner AL (1991) Gene targeting and gene trap screens using embryonic stem cells: new approaches to mammalian development BioEssays $13649-656$

Koller BH and Smithies O (1992) Altering genes in animals by gene targeting Annual Reviews of Immunology 10 705-730

Koller BH, Hagemann LJ, Doetchsman T, Hagaman JR, Huang S, Williams BJ, First NL, Maeda N and Smithies O (1989) Germ-line transmission of a planned alteration made in a hypoxanthine phosphoribosyltransferase gene by homogolous recombination in embryonic stem cells Proceedings of the National Academy of Sciences USA 86 8927-8931

Mann GB, Fowler KJ, Gabriel A, Nice EC, Williams RL and Dunn AR (1993) Mice with a null mutation of the TGF- $\alpha$ gene have abnormal skin architecture, wavy hair, and curly whiskers and frequently develop corneal inflammation Cell 73 249-261

Martin GR (1981) Isolation of pluripotent cell line from early mouse embryos cultured in medium conditioned by teratocarcinoma stem cells Proceedings of the National Academy of Sciences USA 73 7634-7638

Mullis K, Faloona F, Scharf S, Saiki S, Horn G and Erlich HA (1986) Specific enzymatic amplification of DNA in vitro: the polymerase chain reaction Cold Spring Harbor Symposium on Quantitative Biology $51263-273$

Pease S, Braghetta P, Gearing D, Grail D and Williams RL (1990) Isolation of embryonic stem (ES) cells in media supplemented with recombinant leukaemia inhibitory factor (LIF) Developmental Biology 141 344-352

Quinn P, Barros C and Whittingham DG (1982) Preservation of hamster oocytes to assay the fertilizing capacity of human spermatozoa Journal of Reproduction and Fertility 66 161-168

Robertson EJ (1987) Embryo-derived stem cell lines. In Teratocarcinomas and Embryonic Stem Cells a Practical Approach, pp 71-112 Ed. EJ Roberston. IRL Press, Oxford, Washington DC

Saiki RK, Gelfand DH, Stoffel S, Scharf SJ, Higuchi R, Horn GT, Mullis KB and Erlich HA (1988) Primer-directed enzymatic amplification of DNA with a thermostable DNA polymerase Science $239487-491$

Schwartzberg PL, Goff SP and Robertson EJ (1989) Germ-line transmission of a c-abl mutation produced by targeted gene disruption in ES cells Science $\mathbf{2 4 6}$ 799-803

Williams RL, Hilton DJ, Pease S, Williams TA, Stewart CL, Gearing DP, Wagner EF, Metcalf D, Nicola NA and Gough NM (1988) Myeloid leukaemia inhibitory factor maintains the developmental potential of embryonic stem cells Nature $336684-687$

Zijlstra M, Li E, Sajjadi F, Subramani S and Jaenisch R (1989) Germ-line transmission of a disrupted $\beta_{2}$-microglobulin gene produced by homologous recombination in embryonic stem cells Nature $342435-438$ 